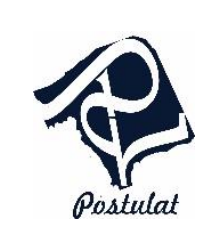

Jurnal Inovasi Pendidikan Matematika

Volume 2, Nomor 1, Juli 2021

\title{
Meningkatkan Keefektifan Pembelajaran Matematika Menggunakan Model Guided Discovery Learning pada Siswa IX-F SMPU Amanatul Ummah
}

\author{
Badrul Mutamam ${ }^{1}$ \\ SMPU Amanatul Ummah ${ }^{1}$; Jl. Siwalankerto Utara No. 56 Surabaya, Siwalankerto, Kec. Wonocolo, Kota \\ Surabaya Prov. Jawa Timur 60236; badrulmutamam@gmail.com
}

\begin{abstract}
This research is a classroom action research which aims to describe the effectiveness of the mathematics learning model using the guided discovery learning model for class IX-F students of SMP Unggulan Amanatul Ummah Surabaya. This research was conducted in 4 stages, namely planning, acting, observating and reflecting. This study shows that learning using the guided discovery learning model can improve student learning outcomes, the ability of teachers to manage learning, and student activities during learning. Based on these three aspects, it can be concluded that learning using the guided discovery learning model can increase effectiveness in learning
\end{abstract}

Keywords: action reasearch, guided discovery learning, mathematic learning

\begin{abstract}
Abstrak
Penelitian ini merupakan penelitian tindakan kelas yang bertujuan untuk mendeskripsikan keefektifan model pembelajaran matematika materi pencerminan dengan menggunakan model guided discovery learning pada peserta didik kelas IX-F SMP Unggulan Amanatul Ummah Surabaya. Penelitian ini dilaksanakan melalui 4 tahap yaitu perencanaan (planning), tindakan (acting), observasi (observating) dan refleksi (reflecting). Penelitian ini menunjukkan bahwa pembelajaran menggunakan model guided discovery learning dapat meningkatan hasil belajar siswa, kemampuan guru dalam megelola pembelajaran, dan aktivitas siswa selama pembelajaran. Berdasarkan ketiga aspek tersebut dapat disimpulkan bahwa pemebelajaran menggunakan model guided discovery learning dapat meningkatkan keefektifan dalam pembelejaran
\end{abstract}

Kata kunci: PTK, guided discovery learning, pembelajaran matematika 
Badrul Mutamam: Meningkatkan Keefektifan Pembelajaran Matematika....

INFO ARTIKEL

\begin{tabular}{l|l}
\hline ISSN $: 2733-0597$ & \multicolumn{1}{c}{ Jejak Artikel } \\
e-ISSN : 2733-0600 & Submit Artikel: \\
DOI $:$ http://dx.doi.org/10.30587/postulat.v2i1.2958 & 2 Oktober 2020 \\
& Submit Revisi: \\
& 23 Maret 2021 \\
& Upload Artikel: \\
& 12 Juli 2021
\end{tabular}

\section{PENDAHULUAN}

Menurut Kemendikbud (2016) tujuan dari kurikulum 2013 adalah untuk mempersiapkan manusia indonesia yang beriman, produktif, kreatif, inovatif, dan efektif serta mampu berkontribusi pada kehidupan bermasyarakat, berbangsa, bernegara dan peradaban dunia. Salah satu tujuan kurikulum 2013 yaitu mempersiapkan manusia yang kreatif. Untuk menjadikan peserta didik menjadi kreatif, seorang guru dituntut untuk bisa mengelola pembelajaran yang menjadikan peserta didik menjadi kreatif. Salah satunya dengan melatih keterampilan peserta didik. keterampilan yang harus dimiliki salah satunya yaitu menyelesaikan masalah. Namun nyatanya hasil kuis peserta didik pada materi pencerminan dari 30 peserta didik hanya 4 peserta didik yang mendapatkan nilai di atas kkm. Hal tersebut dapat dikatakan bahwa pembelajaran materi pencerminan tidak berhasil.

Penyebab rendahnya hasil belajar peserta didik salah satunya disebabkan karena model pembelajaran yang digunakan oleh guru. Hal tersebut dipertegas pendapat dari Slameto (2013) faktor-faktor yang mempengaruhi prestasi belajar ada dua faktor, yaitu faktor intern dan ekstern. Dalam faktor ekstern terbagi menjadi 3 faktor yaitu, faktor keluarga, faktor sekolah dan faktor masyarakat. Pada faktor sekolah yang mempengaruhi hasil belajar salah satunya yaitu model dan metode mengajar. Lebih lanjut menurut Slameto (2013, p. 65) “... model dan metode mengajar itu mempengaruhi hasil belajar".

Berdasarkan hal tersebut peneliti melakukan evaluasi diri dengan menganalisis model pembelajaran yang telah digunakan. Hasil evaluasi diri, langkah-langkah 
pembelajaran yang telah dilakukan untuk materi pencerminan yakni, peneliti mendemonstrasikan penemuan rumus pencerminan melalui pengamatan terhadap pola koordinat objek dan bayangannya dengan metode tanya jawab dengan peserta didik, memberikan contoh soal dan pembahasan. Dari evaluasi diri peneliti dapat dikatakan bahwa pembelajaran yang diterapkan oleh guru yaitu model pembelajaran konvensional. Model pembelajaran konvensional merupakan pembelajaran yang berpusat pada guru.

Untuk mengatasi masalah tersebut, dalam penelitian ini peneliti menawarkan model pembelajaran untuk pembelajaran matematika di kelas IX-F pada materi pencerminan dengan model pembelajaran guided discovery learning. Dengan melakukan inovasi pada model pembelajaran diharapkan kualitas proses maupun hasil belajar dapat ditingkatkan. Melalui model pembelajaran guided discovery learning ini peserta didik diharapkan dapat menemukan sifat-sifat dan rumus pencerminan dengan cara menggambar dan penemuan berbantuan LKPD. Jadi dalam pembelajaran yang terlibat aktif adalah peserta didik, guru hanya sebagai fasilitator.

Model pembelajaran guided discovery learning adalah model pembelajaran yang menekankan adanya pemahaman struktur atau ide-ide penting terhadap suatu disiplin ilmu, melalui keterlibatan peserta didik secara aktif dalam proses pembelajaran. Strategi guided discovery learning ini dilakukan dengan langkah-langkah: Stimulasi (stimulation), Identifikasi masalah (problem statement), Pengumpulan data (data collecting), Pengolahan data (data processing), Verifikasi (verification), Generalisasi (generalization). Dalam pembelajaran dengan penemuan, peserta didik didorong untuk belajar sebagian besar melalui keterlibatan aktif mereka sendiri dengan konsep-konsep dan prinsip-prinsip, dan guru mendorong peserta didik untuk memiliki pengalaman dan melakukan percobaan yang memungkinkan mereka menemukan prinsip-prinsip untuk diri mereka sendiri. Dengan pembelajaran ini pembelajaran aktif lebih menekankan pada pendekatan pembelajaran, dengan esensi mengaktifkan peserta didik dalam pembelajaran yang dilaksanakan dengan strategi pembelajaran berbasis peserta didik (student- centered learning). 
Badrul Mutamam: Meningkatkan Keefektifan Pembelajaran Matematika....

Hasil penelitian Sarnawiah (2019) yang menjelaskan bahwa terjadi peningkatan Nilai rata-rata kelas pada siklus I adalah 62,07 dan pada siklus II adalah 82,76. Sedangkan Menurut hasil penelitian Ismah \& Sundi (2018) yang menjelaskan bahwa penerapan model pembelajaran discovery learning dapat meningkatkan hasil belajar matematika materi himpunan peserta didik kelas VII SMP Labschool Fakultas Ilmu Pendidikan Universitas Muhammadiyah Jakarta

Berdasarkan penjelasan di atas, maka peneliti tertarik untuk melakukan penelitian dengan judul "Meningkatkan Keefektifan Pembelajaran Matematika Menggunakan Model Guided Discovery Learning pada Siswa IX-F SMPU Amanatul Ummah”.

\section{METODE PENELITIAN}

Penelitian ini merupakan penelitian tindakan kelas yang dilakukan dalam 4 (empat) tahap yaitu: perencanaan (planning), tindakan (acting), observasi (observating) dan refleksi (reflecting). Untuk mengatasi suatu permasalahan di kelas, peneliti memerlukan lebih dari satu siklus. Siklus-siklus tersebut saling berkaitan dan berkelanjutan. Apabila pada siklus pertama masih ada hal-hal yang kurang maka dilaksanakan siklus kedua, dan begitu juga pada siklus-siklus berikutnya. Tahapan dalam siklus ini adalah sebagai berikut.

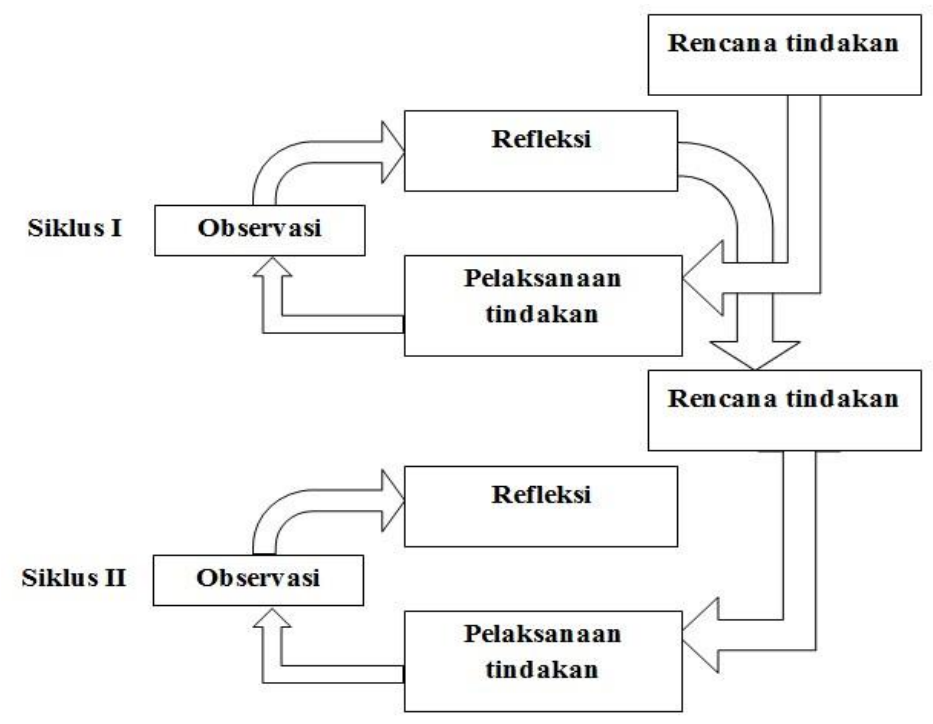

Gambar 1. Tahapan Siklus PTK 
Subjek dalam penelitian ini adalah diswa kelas IX-F SMP Unggulan Amanatul Ummah.

\section{HASIL PENELITIAN}

Penelitian dilakukan pada peserta didik kelas IX F SMP Unggulan Amanatul Ummah. Penelitian ini dilaksanakan sebanyak 3 siklus sesuai dengan RPP dan disetiap akhir siklus diadakan tes hasil belajar.

Berikut deskripsi hasil penelitian

\section{Siklus I}

1. Peningkatan hasil belajar

Berikut presentase hasil belajar peserta didik siklus I

Tabel 1 Presentase Hasil Belajar Peserta Didik Siklus I

\begin{tabular}{|c|c|c|c|c|c|}
\hline \multirow[b]{2}{*}{ Tahapan } & \multirow{2}{*}{$\begin{array}{c}\text { Jumlah } \\
\text { Peserta } \\
\text { didik }\end{array}$} & \multicolumn{3}{|c|}{ Nilai } & \multirow{2}{*}{ Peningkatan } \\
\hline & & Tuntas & $\begin{array}{c}\text { Tidak } \\
\text { Tuntas }\end{array}$ & Rerata & \\
\hline $\begin{array}{l}\text { Skor } \\
\text { Dasar }\end{array}$ & 30 & $\begin{array}{c}10 \\
(33,33 \%)\end{array}$ & $\begin{array}{c}20 \\
(66,67 \%)\end{array}$ & 74,20 & \\
\hline Siklus I & 30 & $\begin{array}{c}23 \\
(76,6 \%) \\
\end{array}$ & $\begin{array}{c}7 \\
(23,33 \%)\end{array}$ & 80,86 & 6,66 \\
\hline
\end{tabular}

2. Kemampuan guru mengelola pembelajaran

Berdasarkan hasil pengamatan terhadap kemampuan guru mengelola pembelajaran dengan model guided discovery learning pada setiap aspek yang diamati, pengamat memberikan nilai 3 dan 4, ini artinya kemampuan guru dalam mengelola pembelajaran di dalam kelas untuk setiap aspek yang diamati untuk setiap pertemuannya berada dalam kategori baik dan sangat baik dan pembelajaran yang dilakukan oleh guru telah sesuai dengan alokasi waktu yang telah ditetapkan di dalam RPP. Guru juga telah mampu membuat siswa aktif dalam belajar dan mampu memberikan bimbingan kepada setiap kelompok yang mengalami kesulitan dalam menyelesaikan LKPD.

3. Aktivitas peserta didik dalam pembelajaran

Hasil pengamatan untuk aktivitas peserta didik selama proses pembelajaran model guided discovery learning pada pencerminan menunjukkan bahwa peserta didik sudah aktif, 
Badrul Mutamam: Meningkatkan Keefektifan Pembelajaran Matematika....

ini berdasarkan persentase Tabel ketujuh indikator mendapatkan nilai persentase di atas $80 \%$. Sebagian besar peserta didik dapat memecahkan masalah dengan berdiskusi, baik diskusi sesama teman dalam kelompok, diskusi dengan kelompok lain maupun diskusi dengan guru. Hal ini relevan dengan Teori belajar sosiokultural Vygotsky yang dikutip dalam Arends (2008) bahwa interaksi sosial peserta didik dalam kelompok dan guru dapat membantu peserta didik untuk membentuk pengetahuan mereka. Berikut beberapa aktivitas peserta didik dalam pembelajaran.

\section{Siklus II}

1. Peningkatan hasil belajar

Berikut presentase hasil belajar peserta didik siklus II

\begin{tabular}{|c|c|c|c|c|c|}
\hline \multirow[b]{2}{*}{ Tahapan } & \multirow{2}{*}{$\begin{array}{c}\text { Jumlah } \\
\text { Peserta } \\
\text { didik }\end{array}$} & \multicolumn{3}{|c|}{ Nilai } & \multirow[b]{2}{*}{ Peningkatan } \\
\hline & & Tuntas & $\begin{array}{c}\text { Tidak } \\
\text { Tuntas }\end{array}$ & Rerata & \\
\hline $\begin{array}{l}\text { Skor } \\
\text { Dasar }\end{array}$ & 30 & $\begin{array}{c}10 \\
(33,33 \%)\end{array}$ & $\begin{array}{c}20 \\
(66,67 \%)\end{array}$ & 74,20 & \\
\hline Siklus II & 30 & $\begin{array}{c}25 \\
(83,33 \%)\end{array}$ & $\begin{array}{c}5 \\
(16.66 \%)\end{array}$ & 82,83 & 8,63 \\
\hline
\end{tabular}

2. Kemampuan guru mengelola pembelajaran

Berdasarkan hasil pengamatan terhadap kemampuan guru mengelola pembelajaran dengan model guided discovery learning pada pencerminan untuk setiap aspek yang diamati, pengamat memberikan nilai 3 dan 4, ini artinya kemampuan guru dalam mengelola pembelajaran di dalam kelas untuk setiap aspek yang diamati untuk setiap pertemuannya berada dalam kategori baik dan sangat baik dan pembelajaran yang dilakukan oleh guru telah sesuai dengan alokasi waktu yang telah ditetapkan di dalam RPP. Guru juga telah mampu membuat peserta didik aktif dalam belajar dan mampu memberikan bimbingan kepada setiap kelompok yang mengalami kesulitan dalam menyelesaikan LKPD.

3. Aktivitas peserta didik dalam pembelajaran

Hasil pengamatan untuk aktivitas peserta didik selama proses pembelajaran model guided discovery learning pada pencerminan menunjukkan bahwa peserta didik sudah aktif, ini berdasarkan persentase Tabel ketujuh indikator mendapatkan nilai persentase di atas $80 \%$. 
Sebagian besar peserta didik dapat memecahkan masalah dengan berdiskusi, baik diskusi sesama teman dalam kelompok, diskusi dengan kelompok lain maupun diskusi dengan guru. Hal ini relevan dengan Teori belajar sosiokultural Vygotsky yang dikutip dalam Arends (2008) bahwa interaksi sosial peserta didik dalam kelompok dan guru dapat membantu peserta didik untuk membentuk pengetahuan mereka.

\section{Siklus III}

1. Peningkatan hasil belajar

Berikut presentase hasil belajar peserta didik siklus III

Tabel 3 presentase hasil belajar peserta didik siklus III

\begin{tabular}{|c|c|c|c|c|c|}
\hline \multirow[b]{2}{*}{ Tahapan } & \multirow{2}{*}{$\begin{array}{c}\text { Jumlah } \\
\text { Peserta } \\
\text { didik }\end{array}$} & \multicolumn{3}{|c|}{ Nilai } & \multirow{2}{*}{ Peningkatan } \\
\hline & & Tuntas & $\begin{array}{c}\text { Tidak } \\
\text { Tuntas }\end{array}$ & Rerata & \\
\hline $\begin{array}{c}\text { Skor } \\
\text { Dasar }\end{array}$ & 30 & $\begin{array}{c}10 \\
(33,33 \%) \\
\end{array}$ & $\begin{array}{c}20 \\
(66,67 \%) \\
\end{array}$ & 74,20 & \\
\hline Siklus III & 30 & $\begin{array}{c}28 \\
(93.33 \%) \\
\end{array}$ & $\begin{array}{c}2 \\
(16.66 \%) \\
\end{array}$ & 84,73 & 10,53 \\
\hline
\end{tabular}

2. Kemampuan guru mengelola pembelajaran

Berdasarkan hasil pengamatan terhadap kemampuan guru mengelola pembelajaran dengan model guided discovery learning pada pencerminan untuk setiap aspek yang diamati, pengamat memberikan nilai 3 dan 4, ini artinya kemampuan guru dalam mengelola pembelajaran di dalam kelas untuk setiap aspek yang diamati untuk setiap pertemuannya berada dalam kategori baik dan sangat baik dan pembelajaran yang dilakukan oleh guru telah sesuai dengan alokasi waktu yang telah ditetapkan di dalam RPP. Guru juga telah mampu membuat peserta didik aktif dalam belajar dan mampu memberikan bimbingan kepada setiap kelompok yang mengalami kesulitan dalam menyelesaikan LKPD.

3. Aktivitas peserta didik dalam pembelajaran

a. Hasil pengamatan untuk aktivitas peserta didik selama proses pembelajaran model guided discovery learning pada pencerminan menunjukkan bahwa peserta didik sudah aktif, ini berdasarkan persentase Tabel ketujuh indikator mendapatkan nilai persentase di atas $80 \%$. Sebagian besar peserta didik dapat memecahkan masalah dengan berdiskusi, baik diskusi sesama teman dalam kelompok, diskusi dengan kelompok lain maupun diskusi 
Badrul Mutamam: Meningkatkan Keefektifan Pembelajaran Matematika....

dengan guru. Hal ini relevan dengan Teori belajar sosiokultural Vygotsky yang dikutip dalam Arends (2008) bahwa interaksi sosial peserta didik dalam kelompok dan guru dapat membantu peserta didik untuk membentuk pengetahuan mereka.

\section{KESIMPULAN, DISKUSI DAN REKOMENDASI}

Berdasarkan hasil penelitian dan pembahasan model pembelajaran matematika materi pencerminan menggunakan model guided discovery learning dapat disimpulkan bahwa pembelajaran matematika materi pencerminan menggunakan model guided discovery learning pada peserta didik kelas IX-F SMP Unggulan Amanatul Ummah dapat meningkatkan keefektifan, hal tersebut terlihat dari:

1. Hasil Belajar Peserta didik

Hasil belajar peserta didik dari 30 peserta didik pada siklus I sebanyak 23 peserta didik mencapai KKM (tuntas), pada siklus II sebanyak 25 peserta didik mencapai KKM (tuntas) dan pada siklus III sebanyak 28 peserta didik mencapai KKM (tuntas). Dari hal tersebut dapat dikatakan bahwa hasil belajar peserta didik setiap siklus mengalami peningkatan

2. Kemampuan Guru Dalam Megelola Pembelajaran

Kemampuan guru mengelola pembelajaran dengan model guided discovery learning pada pencerminan untuk setiap aspek yang diamati pada siklus I, II dan III, pengamat memberikan nilai 3 dan 4, ini artinya kemampuan guru dalam mengelola pembelajaran di dalam kelas untuk setiap aspek yang diamati untuk setiap pertemuannya berada dalam kategori baik dan sangat baik dan pembelajaran yang dilakukan oleh guru telah sesuai dengan alokasi waktu yang telah ditetapkan di dalam RPP.

3. Aktivitas Peserta Didik Dalam Pembelajaran Model Guided Discovery Learning

Aktivitas peserta didik selama proses pembelajaran model guided discovery learning pada pencerminan di siklus I, II dan III menunjukkan bahwa peserta didik sudah aktif, ini berdasarkan persentase Tabel ketujuh indikator mendapatkan nilai persentase di atas $80 \%$.

Berdasarkan hasil penelitian peneliti merekomendasikan: 
1. Pembelajaran model guided discovery learning dapat digunakan untuk materi matematika lainnya, karena terbukti dapat meningkatkan keefektifan pembelajaran

2. Pihak sekolah harus memberi motivasi kepada guru, antara lain dengan cara memberi penghargaan kepada guru yang menunjukkan kinerja yang baik serta guru yang melakukan inovasi dalam kegiatan pembelajaran

\section{UCAPAN TERIMA KASIH}

Penulis menyadari bahwa penulisan laporan PTK ini tidak lepas dari bimbingan, bantuan dan dukungan dari berbagai pihak. Untuk itu, penulis menyampaikan terima kasih yang sebesar-besarnya kepada:

- Bapak Dr. Sarwo Edy, M.Pd. selaku dosen pengampu PPG dalam jabatan di Universitas Muhammadiyah Gresik.

- Bapak Dr. H. Saifuddin Chalim, M.A. Selaku kepala SMP Unggulan Amanatul Ummah yang telah memberikan izin mengikuti PPG dan melaksanakan penelitian tindakan kelas di sekolah.

- Bapak Drs. Dzulkifli Efendi, M.Pd. selaku guru pamong pendidikan profesi guru di Universitas Muhammadiyah Gresik.

- Istri tercinta Evi Novita Wulandari yang senantiasa memberikan dukungan, bantuan dan selalu mendoakan selama PPG dan penyusunan laporan PTK.

- Keluarga tercinta yang selalu memberikan doa dan semangatnya selama PPG dan penyusunan laporan PTK.

- Rekan-rekan seperjuangan PPG Dalam Jabatan angkatan 1 di Universitas Muhammadiyah Gresik

\section{DAFTAR PUSTAKA}

Abdurrahman, M. (2003). Pendidikan Bagi Anak Berkesulitan Belajar. Jakarta: PT. Renika Cipta.

Ahmad, R. (2004). Pengelolaan Pengajaran. Jakarta. Rhineka Cipta Arikunto, Suharsimi. (1992). Prosedur Penelitian. Rineka Cipta: Jakarta.

Arikunto, S. (2002). Prosedur Penelitian. Jakarta: Rineka Cipta.

Dalyono, M. (2007). Psikologi Pendidikan (Komponen MKDK). Jakarta: Rineka Cipta 
Badrul Mutamam: Meningkatkan Keefektifan Pembelajaran Matematika....

Degeng, I Nyoman S. (1989). Ilmu Pengajaran Taksonomi Variabel. Jakarta: Departemen Pendidikan dan Kebudayaan.

Djaelani, et. al. (2011). Meningkatkan Kemampuan Penyelesaian Soal Cerita dalam Matematika Melalui Metode Problem Based Learning. Surakarta: jurnal tidak diterbitkan

Mulyatiningsih, E. (2011). Metode Penelitian Terapan Bidang Pendidikan. Yogyakarta: Alfabeta.

Gholamian, A. (2013). Studying the effect of guided discovery learning on reinforcing the creative thinking of sixth grade girl students in qom during 2012-2013 academic year. Journal of Applied Science and Agriculture, 8 (5). 576-584.

Hanafiah \& Suhana. (2010). Konsep Strategi Pembelajaran. Bandung: PT Refika Aditama.

Hasbullah. (2005). Dasar-Dasar ilmu Pendidikan. Jakarta: PT. Raja Grafindo Persada.

Hidayanti, et. al. (2016). Analisis Kemampuan Berpikir Kritis SMP Kelas IX Pada Materi Kesebangunan. Surakarta: Konferensi Nasional Penelitian Matematika dan Pembelajarannya Universitas Muhammadiyah, ISSN 2502-6526, Hlm. 276-285.

Hidayat. (1986). Teori Efektivitas dalam Kinerja Karyawan. Yogyakarta: Gajah Mada university Press.

Hosnan. (2014). Pendekatan Saintifik dan Kontekstual dalam Pembelajaran Abad 21. Bogor: Ghalia Indonesia.

Ismah \& Sundi, V. H. (2018). Penerapan Model Discovery Learning Untuk Meningkatkan Hasil Belajar Matematika Peserta didik Kelas VII Smp Labschool FIP UMJ. Jurnal Pendidikan Matematika dan Matematika FIBONACCI Volume 4 No. 2 Bulan Desember Tahun 2018.

Kemendikbud. (2016). Silabus Mata Pelajaran Sekolah Menengah Atas/Madrasah Aliyah (SMA/ MA). Jakarta: Kementerian Pendidikan danKebudayaan.

Kemp, J. E., Morrison, G. R., \& Ross, S. M. (2011). Designing EffectivevInstruction 6th Edition. New York: Macmillan College Publishing Company.

Kusuma, W. (2011). Penelitian Tindakan Kelas. Jakarta: PT Indeks

Suryosubroto, B. (2002). Proses Belajar Mengajar di Sekolah. Jakarta: Rineka Cipta.

Suwangsih, E. \& Tiurlina. (2006). Model Pembelajaran Matematika. Bandung: UPI Press.

Winataputra. (2008). Teori Belajar dan Pembelajaran. Jakarta: Universitas Terbuka. 